\title{
COMPOSITION AND DISTRIBUTION OF COMMON REED (PHRAGMITES AUSTRALIS) ALONG AN URBANIZED RIVER: A CASE FROM CENTRAL JAPAN
}

\author{
CAO, Y.* - NATUHARA, Y. \\ Graduate School of Environmental Studies, Nagoya University, Nagoya 4648601, Japan \\ ${ }^{*}$ Corresponding author \\ e-mail:cao0019@outlook.com \\ (Received 20 $0^{\text {th }}$ Nov 2019; accepted $23^{\text {rd }}$ Mar 2020)
}

\begin{abstract}
As an attraction of anthropogenic activity, the impact of artificial disturbance on riparian ecosystems is an increasingly ecological question. However, how riparian species response to urbanization and human disturbance is unclear. This research aimed to study the relationship between ecological characteristics of the common reed and environmental factors along an urbanized river. The 40 sampling plots along the Shonai River that run across the urban and suburban areas of central Japan were investigated. The distribution of common reed was investigated in six plant community types with different species composition. We found that common reed with a dominant stand tends to distributed in the riparian habitats that close to the river while far from roads. Our results showed that the soil properties such as electrical conductivity, and $\mathrm{pH}$ were negatively related to the colonization of common reed. Among the anthropogenic factors, the percentage of impervious surface and distance to the road had a negative correlation with the coverage and biomass of common reed. These results suggested that the negative effects of anthropogenic impacts on the ecology of common reed, and appropriate management should be conducted to maintain the sustainability in riparian areas.
\end{abstract}

Keywords: common reed, urban ecology, riparian areas, vegetation-environment interactions, land cover, soil property

\section{Introduction}

Riparian areas are aquatic-terrestrial ecotones formed by fluvial and upland ecological process, are comprised of a series of heterogonous environments and various vegetation communities (Décamps et al., 2009). Vegetation composition and diversity within the riparian area are highly variable due to the influence of various environmental factors (e.g., flooding regime, soil condition, topography, and anthropogenic disturbances), which restrict the occurrence and colonization of riparian species (Lyon and Gross, 2005). Also, riparian areas are the most sensitive ecosystem compare with the surrounding environment, but also the most severely disturbed by human beings globally (González et al., 2017).

Urbanization and human impact driving profound changes to the natural ecosystems that remain with urbanized areas (Zipperer et al., 2012). In riparian areas, urbanization and the human impact such as land-use change, the construction of flood protection works, soil and water pollution, and human trampling would be associated with the structure and distribution patterns of riparian plant communities (Cao, 2019). However, there are few studies on the distribution pattern of riparian plant species at a local level, despite the availability of some studies referring to the correspondence with habitat conditions and distribution patterns of main component species of riparian area (Mligo, 2016). Few studies have been conducted to focus on the effect of land-use and human impact on the composition and distribution patterns of riparian plant species. 
Common reed (Phragmites australis) is a constructive species in the riparian areas in Japan and is widely distributed from subtropical to cold zones because of its well-adapted ability to a large variety of environments (Clevering and Lissner, 1999). In Asia, the common reed is a native aquatic plant species that provide habitats and breeding sites for birds and insects, and amphibians (Packer et al., 2017), and play a crucial role in stabilization of riparian ecosystem (SijiMol et al., 2016).

In natural riparian habitats that with less human disturbance, common reed can rapidly colonize large areas, and often represent a dominant stand in areas such as wetland, and marshland, where they can form a single species community; this phenomenon has been reported in previous research (McCormick, 2009; Uddin et al., 2017). The ecology and colonization of common reed along the urbanized river where under a high level of human disturbance is still unclear. Indeed, previous studies have mainly focused on the natural environmental variables that affect the ecology of common reed (e.g., moisture and soil properties), but the impact of anthropogenic disturbance on the colonization of this species has received little attention (Burdick et al., 2001; Hudon et al., 2005; Thevs, 2007). For example, the impervious surface, transformed from natural or semi-natural riparian habitats, which in turn can alter the environmental conditions (e.g., soil properties, habitat fragmentation, resource availability), leading to degradation of riparian habitats and vegetation (Grella et al., 2018). The construction and existence of roads, as an index of accessibility to anthropogenic disturbance, have shown deleterious effects on numerous ecosystems (Liu et al., 2014). Generally, there are three main ecological influences of road. Firstly, roads can be corridors for the spread and propagation of alien species (Lázaro-Lobo and Ervin, 2019); secondly, the access of human and vehicles may alter the plant community structure and decrease habitat resilience (Daryanto et al., 2013); thirdly, roads leading the habitat loss and fragmentation, which may negatively affect the colonization and growth of native species (Haddad et al., 2015). Therefore, it limits our understanding of the ecology of common reed if we lose sight of anthropogenic factors, particularly in riparian areas along an urbanized river, which are characterized by fragmented habitats and intense artificial activities.

We studied the distribution pattern and colonization of common reed along the Shonai River, Japan. Our objective was to explore the distribution pattern of common reed and explore the relationship between the colonization of common reed and environmental factors. We hypothesize the common reed with a dominant stand tend to distribute in habitats that under less human-disturbed and, we also hypothesizing that colonization of common reed is negatively affected by anthropogenic pressure.

\section{Methods}

\section{Study area}

The Shonai River runs through the Aichi and Gifu prefecture, Japan $\left(35^{\circ} 04^{\prime}-35^{\circ} 24^{\prime} \mathrm{N}\right.$, $136^{\circ} 49^{\prime}-137^{\circ} 20^{\prime}$ E) (Figure 1). The Shonai River originates from Mt. Yudachi, goes through the basin of Gifu - Tohnoh District, Tamano Valley, Nobi plain, and finally out to the Ise Bay. The basin of the Shonai River covers an area of $1010 \mathrm{~km}^{2}$, and the length of the mainstream is $96 \mathrm{~km}$. The river basin area has a typical temperate maritime climate, the monthly maximum and minimum temperatures were $27.8^{\circ} \mathrm{C}$ (August) and $4.5^{\circ} \mathrm{C}$ (January), respectively. The average annual air temperature and precipitation in 1998-2018 was15.8 and 1529 mm, respectively (Aichi Prefectural Government, 2019). The Shonai River is considered one of the most urbanized rivers in Japan because it has 
been affected by various processes of migration and urban development. The Shonai basin has Nagoya, the fourth largest city in Japan, as well as other rapidly urbanizing cities such as Kasugai, Owari-Asahi, Seto, and Tajimi, with a population density of approximately 2400 persons $/ \mathrm{km}^{2}$. The land use of the Shonai River basin comprises built-up areas (55.2\%), agricultural fields (10.7\%), and forest (34.1\%) (Ministry of Land, Infrastructure, Transport and Tourism, 2018).

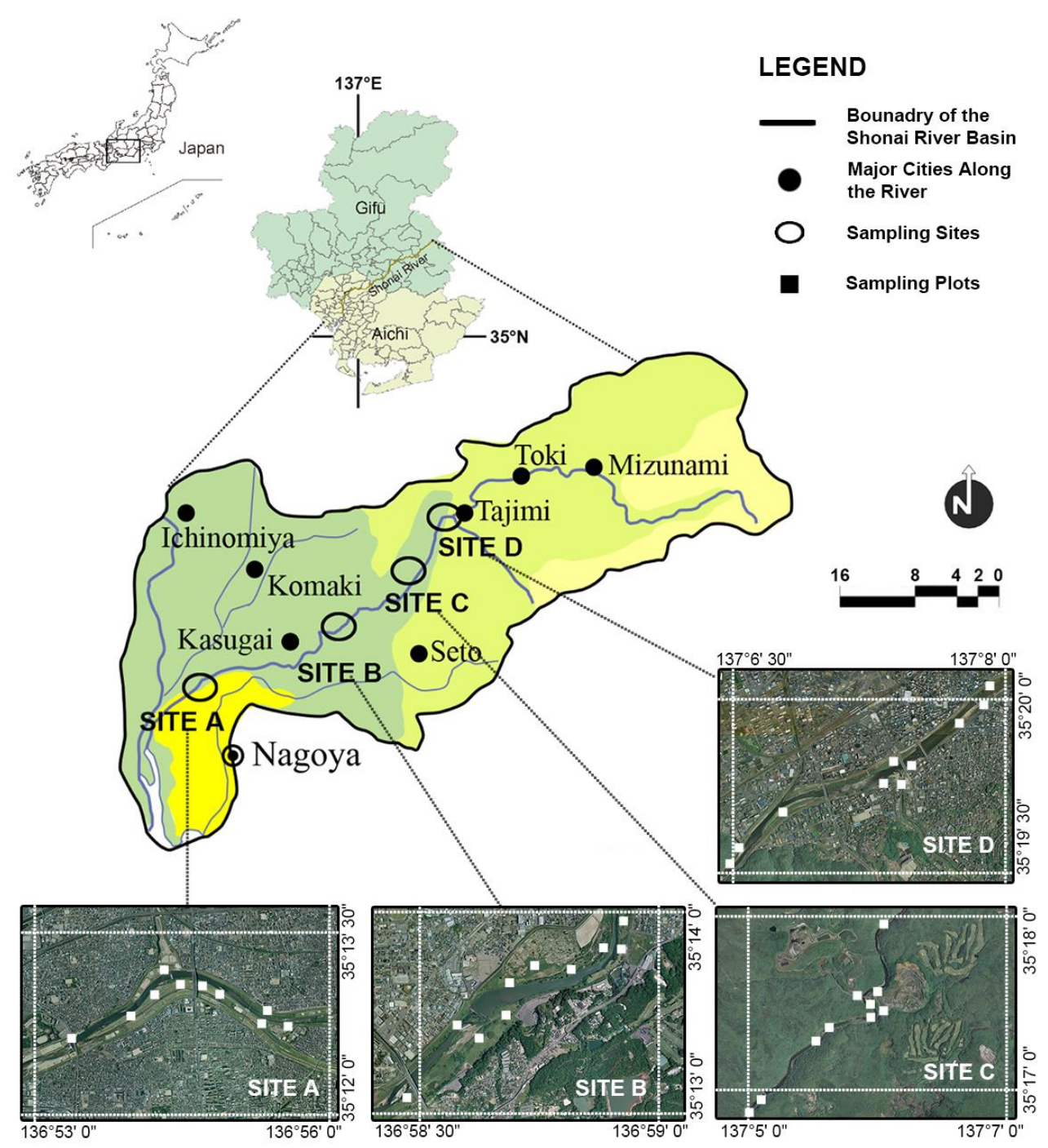

Figure 1. Locations of the study sites, sampling plots, and an overview of the Shonai River system in Japan

\section{Sampling design}

The field survey was conducted from April to July in 2018. Four sampling sites were selected from the lower to upper reaches of the Shonai River. Site A was located to the northwest of Nagoya City, in the lower reaches of the river section. This area has developed over a long period and contains a large human population and recreational spaces. Sites B and C were located outside the urban area, in the middle reaches of the river section, which is undergoing the process of city expansion and is associated with 
the continued disappearance of forest and farmland. Site D was located in the upper reaches of the river system. As the central region of Tajimi City, this area is inhabited by a large number of local residents (Table 1).

Table 1. The description and characteristics of each sampling site

\begin{tabular}{|c|c|c|c|c|c|}
\hline $\begin{array}{l}\text { Sampling } \\
\text { site }\end{array}$ & $\begin{array}{c}\text { Plots } \\
\text { surveyed }\end{array}$ & Sampling site description & $\begin{array}{l}\text { Alt } \\
\text { varia } \\
\text { Min } \\
\end{array}$ & $\begin{array}{l}\text { Ide } \\
\text { n(m) } \\
\text { Max }\end{array}$ & $\begin{array}{l}\text { Example image of } \\
\text { surveyed habitats }\end{array}$ \\
\hline Site A & 10 & $\begin{array}{l}\text { Site A was located to the northwest of } \\
\text { densely built metropolitan city Nagoya. The } \\
\text { riparian area in Site A was transformed by } \\
\text { the levee, recreational spaces, and different } \\
\text { levels of roads. }\end{array}$ & 7.4 & 11.3 & \\
\hline Site B & 10 & $\begin{array}{l}\text { Sites B was located in the suburban region of } \\
\text { Nagoya city. The riparian area was } \\
\text { surrounded by a few small patches of } \\
\text { farmland and residential areas. }\end{array}$ & 16.5 & 20.1 & \\
\hline Site C & 10 & $\begin{array}{l}\text { Site } C \text { was located in the middle reaches of } \\
\text { the river section. The riparian area remains a } \\
\text { semi-natural state with continuous shrub and } \\
\text { grassland. }\end{array}$ & 43.8 & 52.1 & \\
\hline Site D & 10 & $\begin{array}{l}\text { Site D was located in the upper reaches of the } \\
\text { river system. In order to make it easy for } \\
\text { everyone to access the river and enjoy the } \\
\text { scenery, the loose inclination at the lower } \\
\text { riverbed was designed. }\end{array}$ & 89.3 & 97.1 & E \\
\hline
\end{tabular}

In each sampling site, ten $10 \times 10 \mathrm{~m}$ plots were established along the river and used for the sampling of woody and shrub species. In each plot, five $1 \times 1 \mathrm{~m}$ small plots were established for the sampling of herbaceous species and nested in the center and four corners of each plot (Figure 2). Plots were separated by a distance $>50 \mathrm{~m}$. To reduce the marginal effect, the areas within five meters from the river were excluded. The plots were selected at random and depended on the presence of common reed.

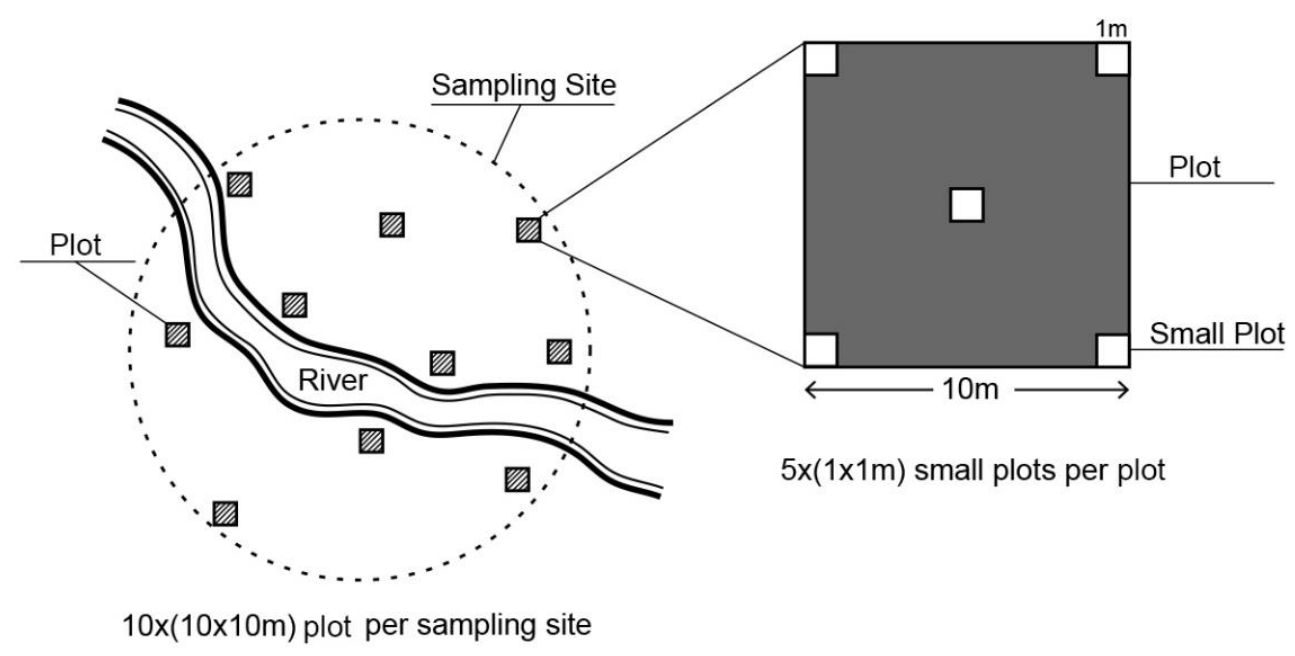

Figure 2. Example of the typical vegetation sampling strategy for each sampling site 


\section{Data collection}

In each plot, we measured a series of variables describing the characteristics of common reed communities and individual: 1) scientific name, coverage, and abundance of all plant species presented in the plot; and 2) the aboveground biomass and density of common reed. The coverage of plant species was measured by visually (Damgaard, 2014); The density of common reed was measured by recording the number of this species in a $1 \times 1 \mathrm{~m}$ range; The aboveground biomass was divided into leaves and stems, and dried at $70^{\circ} \mathrm{C}$ until constant weight (Sinacore et al., 2017). The results were showed in $\mathrm{g}$ dry mass $\mathrm{m}^{-2}$. From each plot, soil samples were collected from the center and four corners of plots at depths $20-40 \mathrm{~cm}$ to analyze the soil physical and chemical properties. To measure the soil water content, each soil sample was placed in an aluminum box and weighed, and after dried in an oven at $105^{\circ} \mathrm{C}$ for $24 \mathrm{~h}$, they were weighed again. The electrical conductivity of each soil sample was tested as follows: first, each of the soil samples was pushed through a $2 \mathrm{~mm}$ sieve, and the solution was conducted as soil: water as 1:5, and then an electromagnetic conductivity meter was used for testing (Mamat et al., 2016). The soil $\mathrm{pH}$ was determined using an electric $\mathrm{pH}$ meter. In addition, in each plot, the distances from the road (DRO) and river (DRI) were calculated using the Euclidean distance method in ArcGIS 9.3. The land use or land cover types in sampling sites were classified by farmland and impervious surface and were calculated based on a color aerial photo and estimated by ArcGIS 9.3. Urban facilities, such as buildings, footpaths, playgrounds, and roads, indicated the impervious surface. Agriculture fields, flower nursery, and orchards were considered as farmland in current research.

\section{Data analysis}

Cluster analysis was used to classify the common reed community types. The importance value (calculated based on the relative frequency, relative coverage, and relative density) of each species present in the 40 plots was used as the basis of cluster analysis (Ruiz and Lugo, 2012; Ross et al., 2016).

The Euclidean distances and Ward's method were used to select an optimum pruning point for the dendrogram. The cluster analysis was performed with $\mathrm{R}$ (version 3.5.1).

To investigate the environmental factors affecting the distribution pattern and composition of common reed communities, we use canonical correspondence analysis (CCA; in CANOCO version 4.5) to ordinate the environment variables. The Monte Carlo permutation test was conducted to examine the statistical significance of environmental variables for CCA.

We conducted two steps of the analysis to explore the relationship between the colonization of common reed and environmental variables. Firstly, we use the Tukey's HSD test in one-way analysis of variance (ANOVA) to explore the differences in the coverage, density, and biomass of common reed among the classified common reed communities; Secondly, we used a generalized linear model constructed with $\mathrm{R}$ to determine the environmental factors affecting the colonization of common reed. The independent environmental variables included elevation $(\mathrm{m})$, precipitation $(\mathrm{mm})$, distance to the river $(\mathrm{m})$, the proportion of impervious surface $(\%)$, the proportion of farmland $(\%)$, distance to the road $(\mathrm{m})$. The factors related to soil property such as soil water content $(\mathrm{g} / \mathrm{g})$, soil electrical conductivity $(\mu \mathrm{S} / \mathrm{cm})$, and $\mathrm{pH}$ were considered in the analysis. We calculated the model with the lowest Akaike information criterion as the best model for the colonization of common reed, using the MASS package. 


\section{Results}

\section{Floristic diversity and composition of common reed community}

In riparian areas along the Shonai River, six groups of common reed communities were classified (Fig. 3). These six groups of communities mainly differed in coverage of common reed and species composition (Table 2). The characteristics of each group of community are as following.

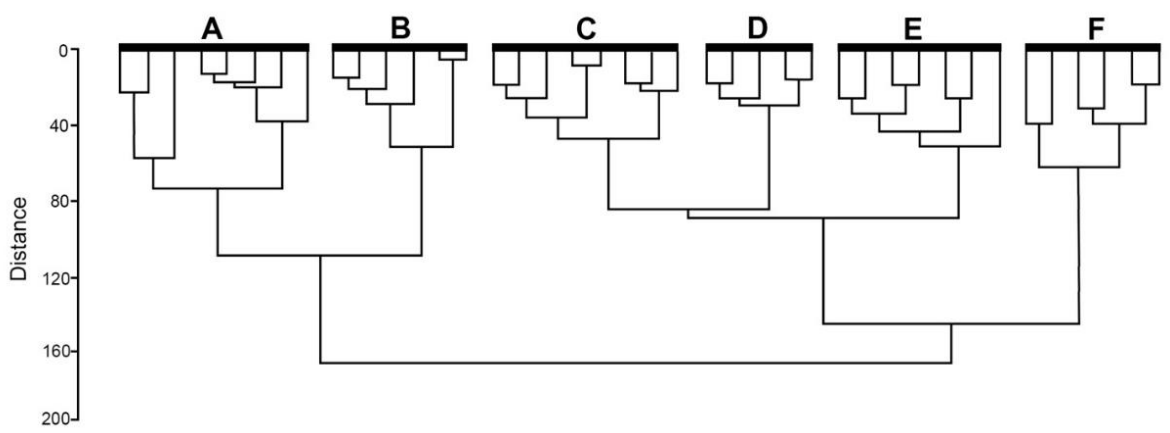

Figure 3. The result of cluster analysis (Ward's method, Euclidean distances), identified six groups of communities

Table 2. Species composition, species frequency $(\mathrm{Fr} \%)$, and mean coverage $(\mathrm{Co} \%)$ within the groups obtained in cluster analysis

\begin{tabular}{|c|c|c|c|c|c|c|c|c|c|c|c|c|}
\hline \multirow[t]{2}{*}{ Species } & \multicolumn{2}{|c|}{ Group A } & \multicolumn{2}{|c|}{ Group B } & \multicolumn{2}{|c|}{ Group C } & \multicolumn{2}{|c|}{ Group D } & \multicolumn{2}{|c|}{ Group E } & \multicolumn{2}{|c|}{ Group F } \\
\hline & $\mathrm{Fr} \%$ & $\mathrm{Co} \%$ & $\mathrm{Fr} \%$ & $\mathrm{Co} \%$ & $\mathrm{Fr} \%$ & $\mathrm{Co} \%$ & Fr\% & $\mathrm{Co} \%$ & $\mathrm{Fr} \%$ & $\mathrm{Co} \%$ & $\mathrm{Fr} \%$ & $\mathrm{Co} \%$ \\
\hline $\begin{array}{c}\text { Erigeron } \\
\text { philadelphicus L.* }\end{array}$ & & & 83.4 & 3.9 & & & 40 & 3.5 & 28.6 & 2.1 & 16.7 & 3.2 \\
\hline $\begin{array}{c}\text { Festuca } \\
\text { arundinacea* }\end{array}$ & 25 & 4.1 & 100 & 32.1 & & & 40 & 3.5 & 28.6 & 2.1 & 16.7 & 3.2 \\
\hline $\begin{array}{l}\text { Lolium multiflorum } \\
\text { Lam.* }\end{array}$ & & & 16.7 & 2.7 & 87.5 & 5.4 & 80 & 5.7 & 59.1 & 5.8 & 16.7 & 3.7 \\
\hline $\begin{array}{c}\text { Miscanthus } \\
\text { sacchariflorus }\end{array}$ & 25 & 6 & 16.7 & 1.9 & 100 & 31.2 & 100 & 34.5 & 100 & 62.1 & & \\
\hline Poa annua $\mathrm{L}$. & 37.5 & 6.5 & & & 62.5 & 3.8 & & & 42.9 & 4.2 & 16.7 & 1.9 \\
\hline $\begin{array}{c}\text { Pueraria montana } \\
\text { var. lobata }\end{array}$ & & & 16.7 & 2.2 & 50 & 5.9 & & & 42.9 & 3.9 & 16.7 & 2.8 \\
\hline $\begin{array}{c}\text { Rosa multiflora } \\
\text { Thunb. }\end{array}$ & 25 & 2.4 & 50 & 2.8 & 62.5 & 4 & 40 & 3.4 & & & 66.7 & 5.2 \\
\hline $\begin{array}{c}\text { Solidago altissima } \\
\text { L.* }\end{array}$ & & & & & 37.5 & 2.7 & 100 & 37.5 & 28.6 & 2.8 & 100 & 32.2 \\
\hline Trifolium repens L. * & 25 & 1.9 & 66.7 & 3.3 & 25 & 2.4 & & & 42.9 & 3.7 & 16.7 & 1.7 \\
\hline $\begin{array}{c}\text { Erigeron annuus (L.) } \\
\text { Pers. } *\end{array}$ & & & 50 & 2.3 & & & 80 & 2.7 & 42.9 & 2.1 & 33.5 & 1.9 \\
\hline
\end{tabular}

The plants represent the accompanying species with common reed. We just listed the top ten species in order of importance value. Non-native species were shown with “*”, the dominant species were shown in bold.

Group A was the common reed community. The structure of Group A communities was dominated by common reed with high coverage.

Group B was the common reed - Festuca arundinacea community. This type of community was dominated by common reed and $F$. arundinacea in the herb layer. 
Group C was the common reed-Miscanthus sacchariflorus community. This type of community was dominated by common reed and M. sacchariflorus. The herb species Solidago altissima was also present in this group of communities.

Group D was the $M$. sacchariflorus-S. altissima community. This type of community was dominated by $M$. sacchariflorus, S. altissima was mainly distributed under the shrub layer, which mainly comprised of M.sacchariflorus. Common reed was sparsely distributed in these communities, with low coverage.

Group E was the M. sacchariflorus community. This group of the community was dominated by $M$. sacchariflorus, with an average coverage of $62.1 \%$. Common reed was distributed associated with $M$. sacchariflorus in the shrub layer with an average coverage of $4.3 \%$.

Group F was the common reed-S. altissima community. This type of community was dominated by common reed and S. altissima.

\section{Distribution and composition pattern of common reed communities}

Canonical correspondence analysis (CCA) was conducted to determine the distribution pattern of the six groups of plant communities. The CCA ordination exhibited strong correlations between plant species abundance and environmental factors. The cumulative proportions for CCA1 and CCA2 were occupied nearly $72 \%$ (Table 3). Therefore, these two axes can be considered proper predictors of plant community distribution and species abundance. The Monte Carlo permutation test indicated that five environmental variables significantly affected the distribution pattern of riparian communities and dominant plant species $(\boldsymbol{P}<0.05)$ (Table 4).

Table 3. Summary statistics for CCA ordinations

\begin{tabular}{c|c|c|c|c}
\hline & CCA1 & CCA2 & CCA3 & CCA4 \\
\hline Eigenvalue & 0.1026 & 0.09177 & 0.03484 & 0.02196 \\
Proportion explained & 0.3809 & 0.3409 & 0.1294 & 0.08156 \\
Cumulative proportion & 0.3809 & 0.72185 & 0.85128 & 0.93284 \\
\hline
\end{tabular}

Table 4. Results of the Monte Carlo permutation test to select the environmental variables for the canonical correspondence analysis $(C C A)$, The significant variables $(p<0.05)$ were selected

\begin{tabular}{c|c|c}
\hline Variables & $\mathbf{R}^{\mathbf{2}}$ & P-value \\
\hline Altitude & 0.2421 & $0.018^{*}$ \\
Distance from the river & 0.2420 & $0.016^{*}$ \\
Distance from the road & 0.3100 & $0.011^{*}$ \\
Proportion of impervious surface & 0.2803 & $0.006^{* *}$ \\
Proportion of farmland & 0.1860 & $0.046^{*}$ \\
\hline
\end{tabular}

$* P \leq 0.05, * * P \leq 0.01$

The CCA1 axis was the best predictor of the differences in the pattern of community distribution and species composition. The correlations between the CCA axes and environmental factors are listed in Table 3. The altitude and proportion of impervious surface were strongly negatively correlated with CCA1; however, the distance from the river, distance from the road, and the proportion of farmland were positively correlated. The distance from the road was positively correlated with CCA2. The factor of the proportion of farmland was positively correlated with the CCA3. None of the environmental factors had a strong relationship with CCA4 (Table 5). 
Table 5. Eigenvalues and correlation matrix of the relationship between the environmental factors and the four axes of the canonical correspondence analysis (CCA) for the six groups of communities growing in the riparian area along the Shonai River

\begin{tabular}{c|c|c|c|c}
\hline Factor & CCA1 & CCA2 & CCA3 & CCA4 \\
\hline Altitude & $-0.7348^{* *}$ & 0.16896 & 0.4996 & 0.4246 \\
Distance from the river & $0.5454^{*}$ & 0.51605 & 0.4222 & 0.1825 \\
Distance from the road & $0.6085^{*}$ & $0.71496^{* *}$ & 0.1237 & 0.2010 \\
Proportion of impervious surface & $-0.8268^{* *}$ & -0.02352 & 0.1758 & -0.3369 \\
Proportion of farmland & $0.6703^{*}$ & -0.02179 & $0.5708^{*}$ & -0.3018 \\
\hline
\end{tabular}

$* P \leq 0.05, * * P \leq 0.01$

The CCA ordination indicates the distribution patterns of the dominant species in each riparian plant community (Figure 4). The distance from the road had an influence on the distribution pattern of community Group1 and most plant communities of Group E. The existence of several dominant species, native species such as $P$. montana var. lobata, was related to the distance from the road. The factor of altitude strongly affected the distribution pattern of Group B and portion of communities of Group A. The species of $F$. arundinacea were strongly associated with the altitude variable. The proportion of impervious surface influenced the distribution of Group B, and part of Group D; the dominant species $S$. altissima and E. philadelphicus was also associated with this variable. The dominant species in Group C and D, and parts of Group E and F, M. sacchariflorus, L. multiflorum, and $P$. апnиa, had obviously positive correlations with the distance from the river (Figure 4 ). The dominant species in Group A and B, common reed, and F. arundinacea had obviously negative correlations with the distance from the river (Figure 4). The proportion of farmland had an influence on the dominant species in Group E. Dominant species, such as $P$. annua and $T$. repens, were associated with the proportion of farmland.

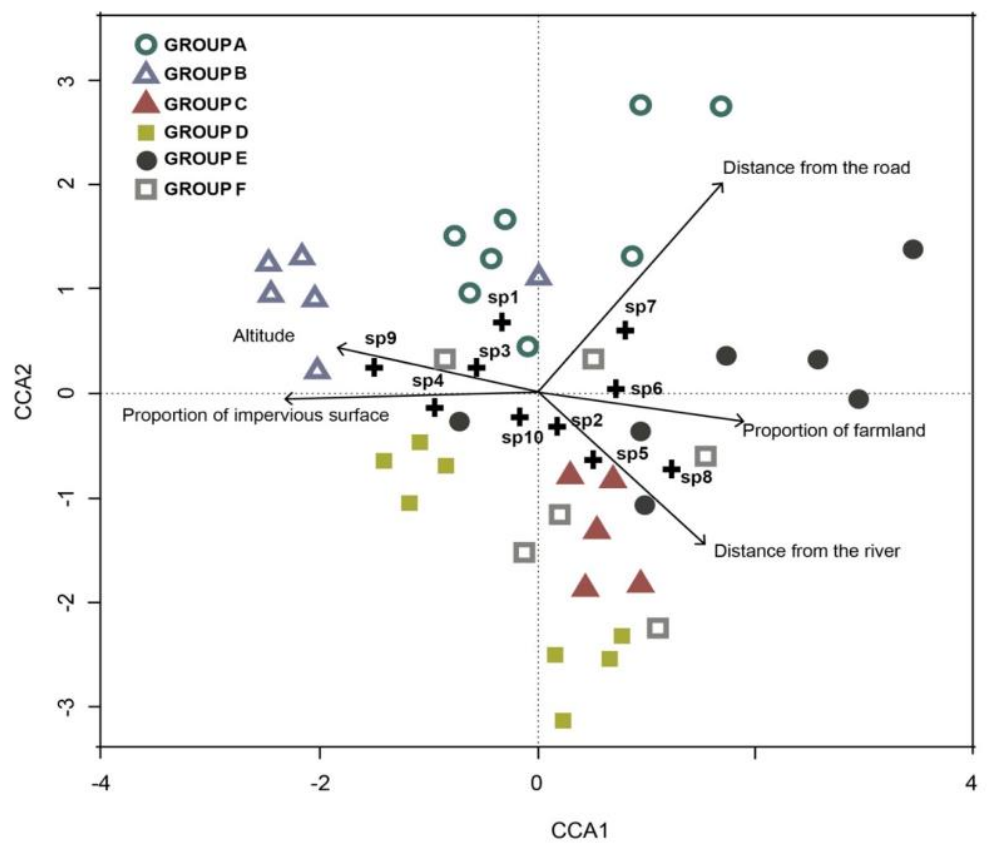

Figure 4. CCA ordination diagram between vegetation characteristics and environmental factors. SP1: common reed; SP2, M. sacchariflorus; SP3, F. arundinacea; SP4, S. altissima; SP5, Lolium multiflorum Lam., SP6, Trifolium repens; SP7, Pueraria montana var. lobata; SP8, Poa annua L. SP9, Erigeron philadelphicus L., SP10, Rosa multiflora Thunb 
These results suggest that the Group A community was located in the area with less anthropogenic disturbance along the Shonai River (long distance to the road, short distance to the river). In contrast, Group B was mainly distributed in areas under high anthropogenic pressure (high proportion of impervious surface, higher altitude). The rural areas of the Shonai River were always associated with the location of Groups C and E (high proportion of farmland). Group D tended to be distributed through areas near the road and far away from the river. The distribution pattern of Group F showed a relatively decentralized condition, but the overall trend was located in the areas far from the river.

\section{Variation in the characteristics of common reed}

The coverage, density, and biomass common reed showed a similar variation tendency in groups A-F (Figure 5).
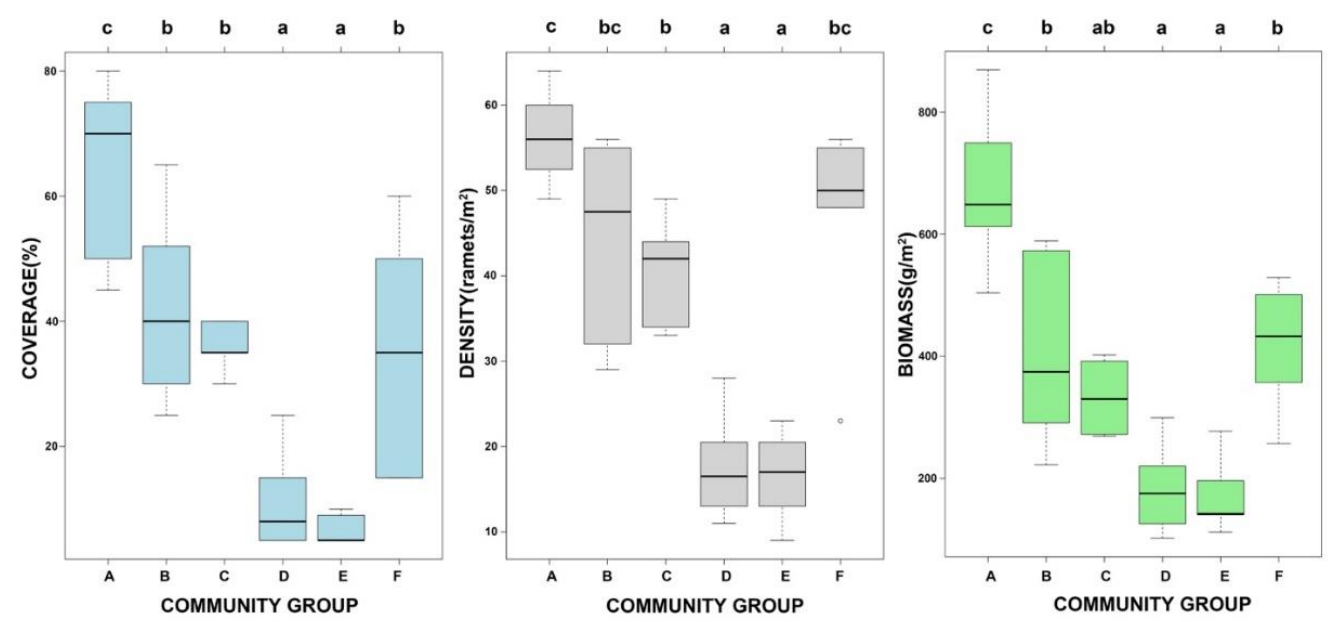

Figure 5. Differences in the coverage, density, and biomass of common reed in the six groups of the plant communities. Values with the same letter means they are not significantly different at the 0.05 significance level

The coverage of common reed showed the highest values in group $\mathrm{A}$ and reached its lowest value in group $\mathrm{E}(\boldsymbol{P}<0.05)$.

The density of common reed showed significantly $(\boldsymbol{P}<0.05)$ higher values in group A while reached its lowest value in group D $(\boldsymbol{P}<0.05)$.

The biomass of common reed reached its highest value in group $\mathrm{A}(\boldsymbol{P}<0.05)$, and showed the lowest value in group $\mathrm{E}$.

\section{Environmental factors affecting the colonization of common reed}

The colonization of common reed in the riparian areas affected by numerous environmental variables in GLM analysis (Table 6 ). The coverage of common reed was highly influenced by soil property (positive/negative) and negatively affected by the distance from the river and the proportion of impervious surface. Besides, the coverage of common reed tends to increase with the increasing of distance from the road. The biomass of common reed was also affected by many factors and was positively correlated with soil water content, distance from the road, and the proportion of farmland. They were also negatively affected by soil electrical conductivity, distance from the river, and 
proportion of impervious surface. The density of common reed was only positively affected by soil water content, but negatively affected by soil electrical conductivity, and the proportion of impervious surface.

Table 6. Generalized linear model (GLM) analysis of the relationship between the colonization of common reed with the environmental factors; electrical conductivity $(E C)$, soil water content (SWC), distance from the river (DRI), distance from the road (DRO), the proportion of impervious surface (IMP), the proportion of farmland(FIELD), altitude (ALT)

\begin{tabular}{c|c|cc|c|c|c|c|c}
\hline & \multicolumn{7}{|c}{ Environmental factors } \\
\cline { 2 - 9 } Characteristics & $\mathrm{pH}$ & $\mathrm{EC}$ & SWC & DRI & DRO & IMP & FIELD & ALT \\
\hline Coverage & $-0.176^{*}$ & $-0.009 * * *$ & $0.006^{* * *}$ & $-0.005^{* * *}$ & $0.001 * *$ & $-0.009 * *$ & & \\
Density & & $-0.005^{* * *}$ & $0.003^{* * *}$ & & & $-0.005^{*}$ & & \\
Biomass & & $-0.004 * * *$ & $0.004 * * *$ & $-0.003 * * *$ & $0.001 * *$ & $-0.003^{* *}$ & $0.006^{* *}$ & \\
\hline
\end{tabular}

The values in the cells are model regression coefficients; only significant coefficients selected for the minimum AIC value are included. *indicates a significant difference $(* P \leq 0.05, * * P \leq 0.01, * * * P \leq 0.001)$.

\section{Discussion}

\section{Distribution and composition pattern of common reed communities}

Regarding the Group A (common reed), a negative correlation between the community distribution and its distance from the river was detected, suggesting that the plant growth in this group depends on the relatively humid environment at the flood plain area of the Shonai River (with distance from the river ranging from 7-55.8 m) (Table 7). The major soil types in the location of Group A near the Shonai River were sandy soil and wet clay, both of which gave exclusive advantages to common reed. On the one hand, due to the unsatisfactory water retention performance of the sandy soil, common reed has a higher survival rate with its remarkable adaptability compared to other species (Rice, 2012; Legault et al., 2018). On the other hand, common reed can grow and spread rapidly in appropriate soil conditions, which makes it more competitive against other species (Ter Heerdt et al., 2017). In addition, the distribution of Group A communities was positively correlated with the distance from roads. This could be explained by the fact that a long distance from roads implies relatively fewer degrees of human disturbance, which could create a relatively stable environment suitable for the growth of vegetation. The distribution pattern of Group A communities accords with our expectation that common reed community tends to distribute in less human-disturbed habitats.

In Group B (common reed- F. arundinacea), it was found that the distribution was also negatively associated with the distance from the river. The suitable moisture environment was leading to high coverage of common reed (Packer et al., 2017). In addition, it was shown that the distribution of the Group B community was positively related to the proportion of impervious surface. A large proportion of impervious surface implies a link to modern management of the rivers for flood control and recreational land use (Washitani, 2001), indicating that this group was at high risk because they would be affected by anthropogenic disturbance (White and Greer, 2006). The various construction works and frequent human disturbance thought to be the major factors facilitating the invasion of alien grasses such as $F$. arundinaceae (Washitani, 2001). The riparian areas along the Shonai River, where the presence of Group B communities was always fragmented by construction measures and combined with other land-use types (e.g., residential areas, 
footpaths, farmlands, golf courses, and parking lots). Consequently, in these areas, common reed was no longer the dominant species. Instead, the alien species in Japan, F. arundinacea (Miyawaki and Washitani, 2004), became another dominant species with a high coverage.

Table 7. Characteristics of environmental factors in the six classified common reed communities. Values represent means $\pm S E$

\begin{tabular}{|c|c|c|c|c|c|c|}
\hline & GROUP A & GROUP B & GROUP C & GROUP D & GROUP E & GROUP F \\
\hline \multicolumn{7}{|c|}{ Distribution feature } \\
\hline & $\begin{array}{l}\text { Near the river } \\
\text { Far from road }\end{array}$ & Near the city & Near farmland & $\begin{array}{c}\text { Near road } \\
\text { Far from river }\end{array}$ & Near farmland & $\begin{array}{c}\text { No obvious } \\
\text { features }\end{array}$ \\
\hline \multicolumn{7}{|c|}{ Potential disturbance } \\
\hline & $\begin{array}{c}\text { Hydrology and } \\
\text { sediment }\end{array}$ & $\begin{array}{c}\text { Human } \\
\text { disturbance }\end{array}$ & $\begin{array}{c}\text { Agriculture } \\
\text { management }\end{array}$ & $\begin{array}{c}\text { Human } \\
\text { disturbance }\end{array}$ & $\begin{array}{c}\text { Agriculture } \\
\text { management }\end{array}$ & --- \\
\hline \multicolumn{7}{|c|}{ Environmental factor } \\
\hline pH & $5.50 \pm 0.18$ & $6.12 \pm 0.04$ & $6.05 \pm 0.21$ & $6.16 \pm 0.21$ & $6.14 \pm 0.13$ & $5.68 \pm 0.27$ \\
\hline $\mathrm{EC}(\mu \mathrm{S} / \mathrm{cm})$ & $45.52 \pm 12.84$ & $46.22 \pm 18.87$ & $51.51 \pm 15.34$ & $96.70 \pm 27.05$ & $90.36 \pm 15.25$ & $86.99 \pm 17.95$ \\
\hline SWC (g/g) & $0.26 \pm 0.04$ & $0.19 \pm 0.02$ & $0.21 \pm 0.02$ & $0.18 \pm 0.01$ & $0.19 \pm 0.01$ & $0.25 \pm 0.03$ \\
\hline DRO(m) & $96.86 \pm 32.79$ & $25.21 \pm 5.83$ & $4.56 \pm 0.88$ & $15.30 \pm 2.95$ & $111.29 \pm 39.48$ & $28.40 \pm 15.73$ \\
\hline DRI(m) & $26.13 \pm 6.95$ & $11.65 \pm 3.30$ & $57.28 \pm 30.44$ & $36.25 \pm 10.34$ & $50.29 \pm 11.33$ & $50.95 \pm 15.31$ \\
\hline IMP $(\%)$ & $3.9 \pm 1.47$ & $25.7 \pm 7.15$ & $8.1 \pm 4.26$ & $17.4 \pm 6.44$ & $6.9 \pm 4.48$ & $13.6 \pm 8.72$ \\
\hline FIELD (\%) & 0 & 0 & $31.2 \pm 14.11$ & $4.9 \pm 2.85$ & $19.7 \pm 8.29$ & $8.3 \pm 5.28$ \\
\hline ALT (m) & $31.25 \pm 5.63$ & $41.87 \pm 11.58$ & $37.12 \pm 12.62$ & $26.81 \pm 9.37$ & $40.22 \pm 21.08$ & $40.15 \pm 14.78$ \\
\hline
\end{tabular}

EC, electrical conductivity; SWC, soil water content; DRO, distance from the road; DRI, distance from the river; IMP, the proportion of impervious surface; FIELD, the proportion of farmland; ALT, altitude

The distribution of Group C (common reed - M. sacchariflorus) and Group E (M. sacchariflorus) communities were mainly positively associated with the proportion of farmland, suggesting that most of them were located in the rural area along the middle part of the Shonai River. Most of these areas were dominated by M. sacchariflorus, which was found along the farmland sides or in agricultural wasteland. Interspecies competition might be a possible explanation for the non-dominant of common reed in Groups $\mathrm{C}$, and E. Common reed and M. sacchariflorus are both hydrophilic plants, and it is widely known that they have similar environmental requirements, but $M$. sacchariflorus has a broader range of adaptation (Yamasaki and Tange, 1981; Yamasaki, 1990). When common reed and $M$. sacchariflorus coexist, common reed may not be vigorous enough to occupy the dominant position. Besides, in previous studies, the soil nutrient and organic matter content in the areas surrounded by farmland was often diversified due to agricultural management (Loveland and Webb, 2003; Santos et al., 2012); the soil with a wide variation on soil nutrient and organic matter content might facilitate the colonization of $M$. sacchariflorus, which affect the growth of common reed.

The distribution of Group D (M. sacchariflorus- S. altissima) communities was positively correlated with the distance from the river. Besides, most of the communities in Group D were also found to be negatively related to the distance from the road, suggesting that the communities of Group D were under the stresses of human disturbance and a relative drought environment. As $M$. sacchariflorus and $S$. altissima are two species with impressive adaptability to a range of different environmental conditions, they became the dominant species in the areas where there were multiple disturbances (Song 
et al., 2016; Szymura and Szymura, 2016). Since it relies on a moist and stable environment to grow, common reed was found to be sparsely distributed in these communities with low coverage.

Although the communities in Group F (common reed - S. altissima) did not demonstrate an obvious distribution pattern, a positive correlation was shown between its vegetation cover extent and the distance from the river in most of these communities, indicating that these plant communities became established in areas far away from the alluvial plain of the river.

\section{Factors determining the colonization of common reed}

The variation in the coverage, density, and biomass of common reed was a result of the interaction between the environmental factors and vegetation. In the current study, we found the soil electrical conductivity and soil water content significantly affected the colonization of common reed. Our results are consistent with those of previous studies concluded that soil moisture and soil properties are major factors that influence the characteristics of vegetation (Oztas et al., 2003; Ursino, 2005). Besides, the surrounding land-use type and the human impact also have a remarkable influence on the colonization of common reed in our research.

As a conventional standard for determining soil salinity, electrical conductivity was negatively correlated with the coverage, density, and biomass of common reed, suggesting that an increase in soil electrical conductivity can inhibit the growth of common reed. Previous studies have demonstrated that electrical conductivity is negatively correlated with the growth of common reed (Lissner and Schierup, 1997; Haraguchi, 2014). Although common reed was well known as a salt tolerance species, with the increase of soil electrical conductivity, density and biomass of common reed were decreased to adapt to the damage of stress. Especially in Groups D and E, where the plant communities were located near to the roads or with a high proportion of farmland, the electrical conductivity of the soil was relatively high among the six groups (Table 7) that may affected by agricultural irrigation methods or intensive human disturbance, leading to a low coverage value of common reed(Wu et al., 2008).

Soil moisture has always been an important factor affecting the growth of common reed in riparian areas (Engloner, 2004). In our study, the soil water content and distance from the river were adopted to measure the effect of soil moisture on the growth of common reed. Consistent with the literature, this research found soil moisture positively related to the colonization of common reed. Due to the short distance from the river and the favorable water holding capacity of the soil in Group 1, the value of the soil water content was the highest in Group 1 (Table 7) compared to that in all the other groups, resulting in a relatively higher coverage, density, and biomass of common reed with large individuals in this group (Figure 5). Although locations close to the river may be subject to flood pressure, all of our sampling sites are located at least 5 meters from the river and are therefore relatively less affected by flooding.

The proportion of impervious surface was negatively associated with the coverage, density, and biomass of common reed. This result indicated that the colonization of common reed is negatively affected by anthropogenic pressure. A significant increase in impervious surfaces may degrade aquatic and terrestrial habitats by aggregating human activities and increasing surface runoff (White and Greer, 2006). Besides, the impervious surfaces tremendously influenced the soil ecosystem by impeding the exchange of water and materials between soil and the atmosphere (Hu et al., 2018). Thus, the inhibition of 
the growth and colonization of common reed might be attributed to the increased impervious surface, and human disturbance enhanced the propagation and growth of wide adaptable and invasive species. Groups B and D, which surrounded by the large proportion of impervious surface, was dominated by invasive species S. altissima, $F$. arundinacea, and accompanied by various ubiquitous species. Also, the inhibition of the growth and colonization of common reed may be the habitat fragmentation associated with the construction of the impervious surface. Fragmentation of habitats destroys essential mechanisms such as dispersion and facilitation, which results in a reduction in the colonization of common reed (de Frutos et al., 2015).

In addition to the anthropogenic disturbance in general, roads, in particular, are important determinants of the plant community characteristics and floristic composition of plants (Root-Bernstein and Svenning, 2018). In our study, it was discovered that the distance from the roads positively affected the coverage and biomass of common reed, indicating that the communities located near the roads are easily influenced by anthropogenic disturbance. The natural riparian habitats could be changed by road, which might result in the alternation of the external environment for the colonization and growth of plants. Previous studies reported that heavy metals accumulation and soil nutrient alternation along the roadside, which might affect the vegetation adjacent to road indirectly (Pagotto et al., 2001; Truscott et al., 2005). Besides, the road can be corridors for the spread and propagation of alien species (Lázaro-Lobo and Ervin, 2019). The previous studies reported that the high species richness of alien species was observed adjacent to the road verge (Zeng et al., 2011). As such, in Group D, the short distance to the road enabled non-native species, such as E. philadelphicus and L. multiflorum, to survive.

\section{Conclusion}

Our study confirmed the importance of moisture and soil properties for the growth and colonization of common reed, which had been reported in previous studies. Meanwhile, we found the anthropogenic factors had significant effects of reduced the population and biomass of common reed. Our findings highlight the effects of land cover types and local environmental conditions on the population variation of riparian plant species. Thus, in riparian areas, management measures, such as restricting construction of public land in riverside, and establishing protective zones for common reed is recommended in future ecological restoration in urban areas. High electrical conductivity value also strongly influenced the colonization of common reed. Thus controlling urban runoff by strengthening supervision and rationally planning urban and river junction zones were suggested in this regard.

However, only 40 sampling plots were selected to determine the characteristics of common reed in this study. This is the deficiency of the sampling design in the current study. Thus, more sampling sites and replicates will be adopted in future work to explore more information about the response of common reed in the urban ecosystem. In addition, there exist many other environmental factors influencing the population of common reed, such as flooding frequency, chemical and physical water characteristics. These factors, as potential co-variates, might affect the variation of common reed in the urban ecosystem. In the future, more factors should be investigated to disentangle the effect of anthropogenic disturbance from hydrological conditions on the colonization of riparian plant species. 
Acknowledgements. We thank reviewers for their suggestions which helped to improve the manuscript. We are grateful to Noelikanto Ramamonjisoa and Yamamoto Mariko for their suggestions on an early version of this manuscript. We thank Wenhui Zhang, Chuan Wu, Xiaohui Zhao and Xiaojun Zheng for the field survey. We thank Claire Oiire and Rhys Nicholls for the spell check.

\section{REFERENCES}

[1] Burdick, D. M., Buchsbaum, R., Holt, E. (2001): Variation in soil salinity associated with expansion of Phragmites australis in salt marshes. - Environmental and Experimental Botany 46(3): 247-261.

[2] Cao, Y., Natuhara, Y. (2019): Effect of Urbanization on Vegetation in Riparian Area: Plant Communities in Artificial and Semi-Natural Habitats. - Sustainability 12(1): 204.

[3] Clevering, O. A., Lissner, J. (1999): Taxonomy, chromosome numbers, clonal diversity and population dynamics of Phragmites australis. - Aquatic Botany 64(3): 185-208.

[4] Damgaard, C. (2014): Estimating mean plant cover from different types of cover data: a coherent statistical framework. - Ecosphere 5(2): 1-7.

[5] Daryanto, S., Eldridge, D. J., Wang, L. (2013): Spatial patterns of infiltration vary with disturbance in a shrub-encroached woodland. - Geomorphology 194: 57-64.

[6] de Frutos, Á., Navarro, T., Pueyo, Y., Alados, C. L. (2015): Inferring resilience to fragmentation-induced changes in plant communities in a semi-arid Mediterranean ecosystem. - PloS one 10(3): e0118837.

[7] Décamps, H., Naiman, R. J., McClain, M. E. (2009): Riparian Zones. - In: Likens, G. E. (ed.) Encyclopedia of Inland Waters. Oxford: Academic Press: 396-403.

[8] Engloner, A. I. (2004): Annual growth dynamics and morphological differences of reed (Phragmites australis [Cav.] Trin. ex Steudel) in relation to water supply. - Flora Morphology, Distribution, Functional Ecology of Plants 199(3): 256-262.

[9] González, E., Felipe-Lucia, M. R., Bourgeois, B., Boz, B., Nilsson, C., Palmer, G., Sher, A. A. (2017): Integrative conservation of riparian zones. - Biological Conservation 211: 20-29.

[10] Grella, C., Renshaw, A., Wright, I. A. (2018): Invasive weeds in urban riparian zones: the influence of catchment imperviousness and soil chemistry across an urbanization gradient. - Urban Ecosystems 21(3): 505-517.

[11] Haddad, N. M., Brudvig, L. A., Clobert, J., Davies, K. F., Gonzalez, A., Holt, R. D., Lovejoy, T. E., Sexton, J. O., Austin, M. P., Collins, C. D., Cook, W. M., Damschen, E. I., Ewers, R. M., Foster, B. L., Jenkins, C. N., King, A. J., Laurance, W. F., Levey, D. J., Margules, C. R., Melbourne, B. A., Nicholls, A. O., Orrock, J. L., Song, D.-X., Townshend, J. R. (2015): Habitat fragmentation and its lasting impact on Earth's ecosystems. - Science Advances 1(2): e1500052.

[12] Haraguchi, A. (2014): Effects of Salinity on Germination, Seedling Growth and Ecological Properties of Phragmites australis Communities in the Estuary of the Chikugogawa River, Southwestern Japan. - American Journal of Plant Sciences 5(5): 584-595.

[13] Hu, Y. D., Li, J. Y., Li, F. (2018): Impervious Surfaces Alter Soil Bacterial Communities in Urban Areas: A Case Study in Beijing, China. - Frontiers in Microbiology 9: 226.

[14] Hudon, C., Gagnon, P., Jean, M. (2005): Hydrological factors controlling the spread of common reed (Phragmites australis) in the St. Lawrence River (Québec, Canada). Écoscience 12(3): 347-357.

[15] Lázaro-Lobo, A., Ervin, G. N. (2019): A global examination on the differential impacts of roadsides on native vs. exotic and weedy plant species. - Global Ecology and Conservation 17: e00555.

[16] Legault, R. II, Zogg, G. P., Travis, S. E. (2018): Competitive interactions between native Spartina alterniflora and non-native Phragmites australis depend on nutrient loading and temperature. - PlosOne 13(2): e0192234. 
[17] Lissner, J., Schierup, H.-H. (1997): Effects of salinity on the growth of Phragmites australis. - Aquatic Botany 55(4): 247-260.

[18] Liu, S., Dong, Y., Deng, L., Liu, Q., Zhao, H., Dong, S. (2014): Forest fragmentation and landscape connectivity change associated with road network extension and city expansion: A case study in the Lancang River Valley. - Ecological Indicators 36: 160-168.

[19] Loveland, P., Webb, J. (2003): Is there a critical level of organic matter in the agricultural soils of temperate regions: a review. - Soil and Tillage Research 70(1): 1-18.

[20] Lyon, J., Gross, N. M. (2005): Patterns of plant diversity and plant-environmental relationships across three riparian corridors. - Forest Ecology and Management 204(2): 267-278.

[21] Mamat, Z., Halik, U., Muhtar, P., Nurmamat, I., Abliz, A., Aishan, T. (2016): Influence of soil moisture and electrical conductivity on the growth of Phragmites australis (Cav.) in the Keriya oasis, China. - Environmental Earth Sciences 75(5): 423.

[22] McCormick, M., Kettenring, K., Weiner, H., Whigham, D (2009): Extent and Reproductive Mechanisms of Phragmites australis Spread in Brackish Wetlands in Chesapeake Bay, Maryland (USA). - Wetlands 30: 67-74.

[23] Miyawaki, S., Washitani, I. (2004): Invasive alien plant species in riparian areas of Japan: the contribution of agricultural weeds, revegetation species and aquacultural species. Global Environmental Research 8(1): 89-101.

[24] Mligo, C. (2016): Diversity and distribution pattern of riparian plant species in the Wami River system, Tanzania. - Journal of Plant Ecology 10(2): 259-270.

[25] Oztas, T., Koc, A., Comakli, B. (2003): Changes in vegetation and soil properties along a slope on overgrazed and eroded rangelands. - Journal of Arid Environments 55(1): 93-100.

[26] Packer, J. G., Meyerson, L. A., Skálová, H., Pyšek, P., Kueffer, C. (2017): Biological Flora of the British Isles: Phragmites australis. - Journal of Ecology 105(4): 1123-1162.

[27] Pagotto, C., Rémy, N., Legret, M., Le Cloirec, P. (2001): Heavy Metal Pollution of Road Dust and Roadside Soil near a Major Rural Highway. - Environmental Technology 22(3): 307-319.

[28] Rice, D., Rooth, J., Stevenson, J. C. (2012): Colonization and expansion of Phragmites Australis in upper Chesapeake Bay tidal marshes. - Wetlands 20: 280.

[29] Root-Bernstein, M., Svenning, J.-C. (2018): Human paths have positive impacts on plant richness and diversity: A meta-analysis. - Ecology and Evolution 8(22): 11111-11121.

[30] Ross, A. M., Johnson, G., Gibbs, J. P. (2016): Spruce grouse decline in maturing lowland boreal forests of New York. - Forest Ecology and Management 359: 118-125.

[31] Ruiz, M. A., Lugo, A. E. (2012): Landscape effects on structure and species composition of tabonuco forests in Puerto Rico: Implications for conservation. - Forest Ecology and Management 266: 138-147.

[32] Santos, V. B., Araújo, A. S. F., Leite, L. F. C., Nunes, L. A. P. L., Melo, W. J. (2012): Soil microbial biomass and organic matter fractions during transition from conventional to organic farming systems. - Geoderma 170: 227-231.

[33] SijiMol, K., Dev, S. A., Sreekumar, V. B. (2016): A Review of the Ecological Functions of Reed Bamboo, Genus Ochlandra in the Western Ghats of India: Implications for Sustainable Conservation. - Tropical Conservation Science 9(1): 389-407.

[34] Sinacore, K., Hall, J. S., Potvin, C., Royo, A. A., Ducey, M. J., Ashton, M. S. (2017): Unearthing the hidden world of roots: Root biomass and architecture differ among species within the same guild. - PlosOne 12(10): e0185934.

[35] Song, J.-S., Lim, S.-H., Lim, Y., Nah, G., Lee, D., Kim, D.-S. (2016): Herbicide-based Weed Management in Miscanthus sacchariflorus. - BioEnergy Research 9(1): 326-334.

[36] Szymura, M., Szymura, T. H. (2016): Interactions between alien goldenrods (Solidago and Euthamia species) and comparison with native species in Central Europe. - Flora Morphology, Distribution, Functional Ecology of Plants 218: 51-61. 
[37] Ter Heerdt, G. N. J., Veen, C. G. F., Van der Putten, W. H., Bakker, J. P. (2017): Effects of temperature, moisture and soil type on seedling emergence and mortality of riparian plant species. - Aquatic Botany 136: 82-94.

[38] Thevs, N., Zerbe, S., Gahlert, F., Mijit, M., Succow, M (2007): Productivity of reed (Phragmites australis Trin. ex Steud.) in continental-arid NW China in relation to soil, groundwater, and land-use. - Journal of Applied Botany and Food Quality 81(1).

[39] Truscott, A. M., Palmer, S. C. F., McGowan, G. M., Cape, J. N., Smart, S. (2005): Vegetation composition of roadside verges in Scotland: the effects of nitrogen deposition, disturbance and management. - Environmental Pollution 136(1): 109-118.

[40] Uddin, M. N., Robinson, R. W., Buultjens, A., Al Harun, M. A. Y., Shampa, S. H. (2017): Role of allelopathy of Phragmites australis in its invasion processes. - Journal of Experimental Marine Biology and Ecology 486: 237-244.

[41] Ursino, N. (2005): The influence of soil properties on the formation of unstable vegetation patterns on hillsides of semiarid catchments. - Advances in Water Resources 28(9): 956963.

[42] Washitani, I. (2001): Plant conservation ecology for management and restoration of riparian habitats of lowland Japan. - Population Ecology 43(3): 189-195.

[43] White, M. D., Greer, K. A. (2006): The effects of watershed urbanization on the stream hydrology and riparian vegetation of Los Peñasquitos Creek, California. - Landscape and Urban Planning 74(2): 125-138.

[44] Wu, J., Vincent, B., Yang, J., Bouarfa, S., Vidal, A. (2008): Remote Sensing Monitoring of Changes in Soil Salinity: A Case Study in Inner Mongolia, China. - Sensors 8(11): 70357049.

[45] Yamasaki, S., Tange, I. (1981): Growth responses of Zizania latifolia, phragmites australis and Miscanthus sacchariflorus to varying inundation. - Aquatic Botany 10: 229-239.

[46] Yamasaki, S. (1990): Population dynamics in overlapping zones of Phragmites australis and sacchriflorus sacchariflorus. - Aquatic Botany 36(4): 367-377.

[47] Zeng, S.-L., Zhang, T.-T., Gao, Y., Ouyang, Z.-T., Chen, J.-K., Li, B., Zhao, B. (2011): Effects of road age and distance on plant biodiversity: a case study in the Yellow River Delta of China. - Plant Ecology 212(7): 1213-1229.

[48] Zipperer, W. C., Foresman, T. W., Walker, S. P., Daniel, C. T. (2012): Ecological consequences of fragmentation and deforestation in an urban landscape: a case study. Urban Ecosystems 15(3): 533-544. 